\title{
Influence of feeding full-fat linseed and rapeseed on the morphology of small intestinal mucosa in broiler chickens*
}

\author{
C.V. Nguyen, M. Biernat and S. Smulikowska ${ }^{1}$ \\ The Kielanowski Institute of Animal Physiology and Nutrition, \\ Polish Academy of Sciences \\ 05-110 Jabłonna, Poland
}

(Received 10 March 2003; accepted 15 July 2003)

\begin{abstract}
Three groups of 12 broiler chickens were fed from 8 to 21 day of life wheat-based, xylanase-supplemented diets containing $80 \mathrm{~g}$ crude fat $/ \mathrm{kg}$; control diet contained lard, diet L $80 \mathrm{~g}$ linseed, diet $\mathrm{R}$ $100 \mathrm{~g}$ rapeseed per $\mathrm{kg}$. Growth performance data were recorded, than 6 chickens from each group were killed after $17 \mathrm{~h}$ of food deprivation, and 3 parts of small intestine were incised, fixed and mounted in paraplast. The histomorphometry of villi, crypts and tunica muscularis and submucosa was performed using light microscopy.

Birds from group L were significantly heavier than from $\mathrm{R}$ group $(\mathrm{P}<0.05)$, due to higher feed intake, other differences were not significant. Histological observations on small intestinal mucosa showed elongation of the villi, greater depth of crypts and greater thickness of intestinal wall in jejunum and ileum in $\mathrm{L}$ and $\mathrm{R}$ chickens in comparison with control group $(\mathrm{P}<0.05)$. The changes in morphological structure of intestinal wall may indicate on a shift in a site of the absorption of nutrients within the digestive tract of chickens fed diets with linseed and rapeseed.
\end{abstract}

KEY WORDS: morphology, small intestine, growth performance, linseed, rapeseed, broiler chickens

\section{INTRODUCTION}

Full-fat linseed and 00 rapeseed (canola) are often evaluated as a source of n-3 fatty acids in broiler chicken diets. However, both contain some potent

\footnotetext{
* Supported by the State Committee for Scientific Research, Grant No. 5 PO6E 03115

${ }^{1}$ Corresponding author
} 
antinutritional factors, what limits their use as a feedstuffs for poultry. Lee et al. (1991) showed, that diets containing 10 or $20 \%$ of canola had no negative effect, while diets with the same levels of flaxseed significantly decreased performance of broiler chickens. Similar results were obtained by Pietras et al. (2000) with diets containing $15 \%$ of these oilseeds. The increase in the dietary inclusion of linseed led to poor digestibility and utilization of nutrients by chickens, what may be attributed mainly to the increase in viscosity of the small intestinal digesta caused by mucilage present in the seeds (Rodriguez et al., 2001). In our research (Smulikowska and Nguyen, unpublished) inclusion of 8,16 or $24 \%$ linseed into chicken diet increased the viscosity of jejunal digesta from 1.5 in control group to 5,9 and 15 mPas.s, respectively, and the viscosity of ileal digesta from 1.8 in control group to 6, 14 and 38 mPas.s, respectively. It is well-known that in chickens the viscosity of digesta is negatively correlated with the digestibility of nutrients, particularly fat, and it may have also impact on intestinal development and functions (Viveros et al., 1994; Smulikowska, 1998; Iji, 1999).

The feeding value of full-fat rapeseed is limited mainly by the presence of glucosinolates, which affect thyroid functions. Rapeseed is also rich in condensed tannins, phytates and non-starch polysaccharides (NSP), however, NSP of rapeseed did not increase the viscosity of intestinal digesta in chickens (Nguyen et al., 2003). There is an evidence that feedstuffs differing in physico-chemical characteristics of dietary fibre affect the development of digestive tract in young birds and alter the morphological structures of small intestinal wall (Jamroz et al., 1992; Viveros et al. 1994; Iji, 1999; Jaroni et al., 1999), however no data on the effect of rapeseed- and linseed-containing diets was found in available literature.

The objective of the study was to investigate an effect of diets with moderate level of linseed and rapeseed on growth performance and on morphology of mucosal layer of small intestinal wall.

\section{MATERIAL AND METHODS}

Commercial brown-seeded linseed and rapeseed '00' were the same as used in the study of Nguyen et al. (2003). Oilseeds were finely ground. Three diets were prepared, control diet without oilseeds, and two isocaloric and isoprotein diets containing $80 \mathrm{~g}$ linseed (L) or $100 \mathrm{~g}$ rapeseed (R) per $\mathrm{kg}$. All diets were supplemented with xylanase (Avizyme 1300, Finnfeeds Int.) and contained growth promoter and coccidiostatic (Table 1). Diets were cold pelleted.

Sixty one-day-old Hybro line female broiler chickens were placed in battery brooder in a temperature-controlled room with continuous light, and fed pre-starter diet. At 8 day of age, the birds were deprived of food for $4 \mathrm{~h}$, weighed, and 36 birds of body weight on average $136 \mathrm{~g}$, were allocated randomly to three groups 
NGUYEN C.V. ET AL.

TABLE 1

Composition of diets, in $\mathrm{g} / \mathrm{kg}$

\begin{tabular}{lrrr}
\hline & & Diet & \\
\cline { 2 - 4 } Ingredients & Control & \multicolumn{2}{c}{$\mathrm{L}$} \\
\hline Maize & 100.0 & 100.0 & 100.0 \\
Soyabean meal & 322.2 & 290.1 & 284.0 \\
Wheat & 477.2 & 459.0 & 454.6 \\
Linseed & - & 80.0 & - \\
Rapeseed & - & - & 100.0 \\
Lard & 60.0 & 30.0 & 20.8 \\
Limestone & 5.0 & 5.0 & 5.0 \\
Dicalcium phosphate & 18.0 & 18.0 & 18.0 \\
NaCl & 3.0 & 3.0 & 3.0 \\
L-lysine (74.8\%) & 2.2 & 2.7 & 2.6 \\
DL-met (96.3\%) & 1.4 & 1.2 & 1.0 \\
Premix* & 10.0 & 10.0 & 1.0 \\
Enzyme** & 1.0 & 1.0 & \\
& & & 210.0 \\
Crude protein & 210.0 & 210.0 & 78.8 \\
Crude fat & 78.8 & 78.8 & . \\
\hline
\end{tabular}

* provided per kg diet: (IU) vit. A 13000; vit. $\mathrm{D}_{3} 3500$; (mg): vit. E 40; vit. $\mathrm{K}_{3}$ 4; vit. $\mathrm{B}_{1} 3$; vit. $\mathrm{B}_{2} 7$; vit. $\mathrm{B}_{6} 5$ (7 in $\mathrm{L}$ diet); vit. $\mathrm{B}_{12} 0.02$; nicotinic acid 45 ; pantothenic acid 16 ; folic acid 1.5; biotine 0.1; choline 400; Mn 80; Zn 60; Fe 70; Cu 10; J 1; Se 0.15; Na 270; Flavomycine 5; Diclazuril 1; Ca $2.25 \mathrm{~g}$; methionine 1g; **Avizyme 1300 (Finnfeeds Int.)

and placed in individual cages $\left(38 \times 50 \times 50 \mathrm{~cm}^{3}\right)$, each equipped with an electrical heater inside and feeding through and water cup outside. The temperature in the room was $25^{\circ} \mathrm{C}$ at the 8 day and was reduced to $22^{\circ} \mathrm{C}$ subsequently. Chickens were fed with experimental diets ad libitum for two weeks. Body weight and feed intake (corrected for feed wastage) was recorded in weekly intervals, after $4 \mathrm{~h}$ food deprivation, and body weight gain and feed conversion ratio was calculated.

At the 22 day of age six chickens from each group were killed by decapitation after $17 \mathrm{~h}$ food deprivation. The small intestine was immediately removed and $3 \mathrm{~cm}$ long segments were taken from the proximal duodenum, the jejunum $(5 \mathrm{~cm}$ anterior from the Meckel's diverticulum) and the ileum $(5 \mathrm{~cm}$ anterior the ileocaecal junction).

Segments of duodenum, jejunum and ileum were fixed in Bouin's solution for 5 days, then dehydrated and embedded in paraplast. Serial histological sections of $5 \mu \mathrm{m}$ thickness were cut from the waxed tissues on a microtome (Microm HM 350). The slides were stained with haematoxylin, counter-stained with eosin and examined under a light microscope. Images were viewed with objective x 2 or x 4 on Nikon optical binocular microscope (Nikon Corporation, Yokohama, Japan), coupled with 
camera (Panasonic KR222, Matsushita Electric Industrial Co., Osaka, Japan) to a computer. Villous height (from tip to crypt mouth), villous width (in the middle of its length), crypt depth (from crypt mouth to base) and width of tunica muscularis and submucosa were measured. Measurements of villous height and crypt depth were taken only from sections, where the plane of section run vertically from the tip of the villus to the base of an adjacent crypt. Averages represented the measurements of at least 6 slides, in each slide 30 well-oriented villi and crypts were measured using Lucia G v 4.60 software (Laboratory Imaging Ltd., Prague, Czech Republic).

Experiment was conduced in compliance with the European Union regulations concerning the protection of experimental animals. The Local Ethics Committee approved the study protocol.

One way-ANOVA and Duncan multiple range tests was used to indicate the statistical differences between the groups (Statgraphics Plus v 5.1, 1994-2001). In all statistical analysis $\mathrm{P}<0.05$ was taken as the level of significance.

\section{RESULTS}

Birds during experiment were healthy, there were no mortality or culling. Growth performance was shown in Table 2. Birds fed diet with linseed were insignificantly heavier than birds from control group and significantly heavier from group fed rapeseed diet $(\mathrm{P}<0.05)$, feed intake in L group was numerically higher, but the differences in feed intake and feed/gain ratio among groups did not reach significance level.

The morphological characteristics of mucosa from three regions of the small intestine is shown in Table 3, while cross sections of the jejunum of control and test birds are presented in Figures 1 and 2. The villi were longest in duodenum, their height gradually declined in jejunum and ileum in all examined groups. Birds fed the diet with linseed and rapeseed had longer villi than control ones (Figure 1). In duodenum this differences were not statistically significant, but in jejunum and ileum reached significance level $(\mathrm{P} \leq 0.05)$. In ileum the villi in birds fed linseed diet were significantly $(\mathrm{P} \leq 0.05)$ higher than in group fed rapeseed diet.

TABLE 2

Influence of linseed and rapeseed on performance of broiler chickens from 8 to 21 days of age

\begin{tabular}{lccc}
\hline Dietary treatment & $\begin{array}{c}\text { Body weight gain } \\
\text { g }\end{array}$ & $\begin{array}{c}\text { Feed intake } \\
\text { g }\end{array}$ & $\begin{array}{c}\text { Feed/gain ratio } \\
\text { g/g }\end{array}$ \\
\hline Control & $591.0^{\mathrm{ab}}$ & 849.6 & 1.44 \\
Linseed & $626.3^{\mathrm{b}}$ & 878.4 & 1.40 \\
Rapeseed & $580.4^{\mathrm{a}}$ & 849.2 & 1.47 \\
Pooled SEM & 13.2 & 21.3 & 0.02 \\
\hline a, b means within a column with different superscripts are significantly different $(\mathrm{P}<0.05)$
\end{tabular}

${ }^{\mathrm{a}, \mathrm{b}}$ means within a column with different superscripts are significantly different $(\mathrm{P} \leq 0.05)$ 
NGUYEN C.V. ET AL.

TABLE 3

Morphological characteristics of different segments of small intestine in 22-day-old chickens fed control or linseed- or rapeseed-containing diets

\begin{tabular}{|c|c|c|c|c|}
\hline \multirow{2}{*}{ Part of small intestine } & \multicolumn{3}{|c|}{ Dietary treatment } & \multirow{2}{*}{$\begin{array}{c}\text { Pooled } \\
\text { SEM }\end{array}$} \\
\hline & control & linseed & rapeseed & \\
\hline \multicolumn{5}{|l|}{ Duodenum } \\
\hline villus height, $\mu \mathrm{m}$ & 1768 & 1957 & 1912 & 106 \\
\hline villus width, $\mu \mathrm{m}$ & 200 & 204 & 221 & 12 \\
\hline crypt depth, $\mu \mathrm{m}$ & $206^{\mathrm{a}}$ & $183^{\mathrm{b}}$ & $201^{\mathrm{a}}$ & 12 \\
\hline \multirow{2}{*}{$\begin{array}{l}\text { villus/crypt ratio, } \mu \mathrm{m} / \mu \mathrm{m} \\
\text { width of tunica muscularis } \\
\text { and submucosa, } \mu \mathrm{m}\end{array}$} & $8.6^{\mathrm{aA}}$ & $10.7^{\mathrm{bB}}$ & $9.5^{\mathrm{aAB}}$ & 0.7 \\
\hline & $191^{\mathrm{aA}}$ & $159^{\mathrm{bA}}$ & $227^{\mathrm{cB}}$ & 8 \\
\hline \multicolumn{5}{|l|}{ Jejunum } \\
\hline villus height, $\mu \mathrm{m}$ & $797^{\mathrm{a}}$ & $1083^{b}$ & $1004^{b}$ & 42 \\
\hline villus width, $\mu \mathrm{m}$ & 140 & 148 & 148 & 19 \\
\hline crypt depth, $\mu \mathrm{m}$ & $140^{\mathrm{a}}$ & $158^{\mathrm{b}}$ & $172^{\mathrm{b}}$ & 9 \\
\hline villus/crypt ratio, $\mu \mathrm{m} / \mu \mathrm{m}$ & 5.7 & 6.8 & 5.8 & 0.4 \\
\hline $\begin{array}{l}\text { width of tunica muscularis } \\
\text { and submucosa, } \mu \mathrm{m}\end{array}$ & $212^{\mathrm{a}}$ & $228^{\mathrm{a}}$ & $253^{\mathrm{b}}$ & 6 \\
\hline \multicolumn{5}{|l|}{ Ileum } \\
\hline villus height, $\mu \mathrm{m}$ & $597^{\mathrm{a}}$ & $868^{\mathrm{c}}$ & $729^{b}$ & 40 \\
\hline villus width, $\mu \mathrm{m}$ & 139 & 142 & 145 & 9 \\
\hline crypt depth, $\mu \mathrm{m}$ & $134^{\mathrm{a}}$ & $140^{\mathrm{a}}$ & $163^{\mathrm{b}}$ & 5 \\
\hline villus/crypt ratio, $\mu \mathrm{m} / \mu \mathrm{m}$ & 4.5 & 6.1 & 4.5 & 0.8 \\
\hline $\begin{array}{l}\text { width of tunica muscularis } \\
\text { and submucosa, } \mu \mathrm{m}\end{array}$ & $198^{\mathrm{a}}$ & $223^{b}$ & $230^{\mathrm{b}}$ & 5 \\
\hline
\end{tabular}

mean in a column with different superscripts are significantly different at: ${ }^{\mathrm{a}, \mathrm{b}} \mathrm{P} \leq 0.05$;

A, B $\mathrm{P} \leq 0.01$

The villi were broader in duodenum, than in more distal parts of the intestine, but there were no significant differences due to treatment (Table 3).

Crypt depth and the ratio of villus height to crypt depth declined from the duodenum to the ileum in all groups. Duodenal crypts were shorter $(\mathrm{P} \leq 0.05)$ in chicks fed with linseed diet than in both remaining groups. At the jejunum and ileum (Figure 2) the shortest crypts were in control group, the deepest in chicks fed rapeseed diet $(\mathrm{P} \leq 0.05)$. In all three parts of the small intestine the ratio of villus height to crypt depth was numerically highest in birds fed linseed diet, than in both other groups, but only in duodenum the difference between $\mathrm{L}$ and control group was significant $(\mathrm{P} \leq 0.05)$. The thickness of the tunica muscularis and submucosa in duodenum and jejunum was significantly $(\mathrm{P} \leq 0.05)$ greater in $\mathrm{R}$ chickens than in control and L group, in ileum it was also in L group greater, than in control (Table 3). 

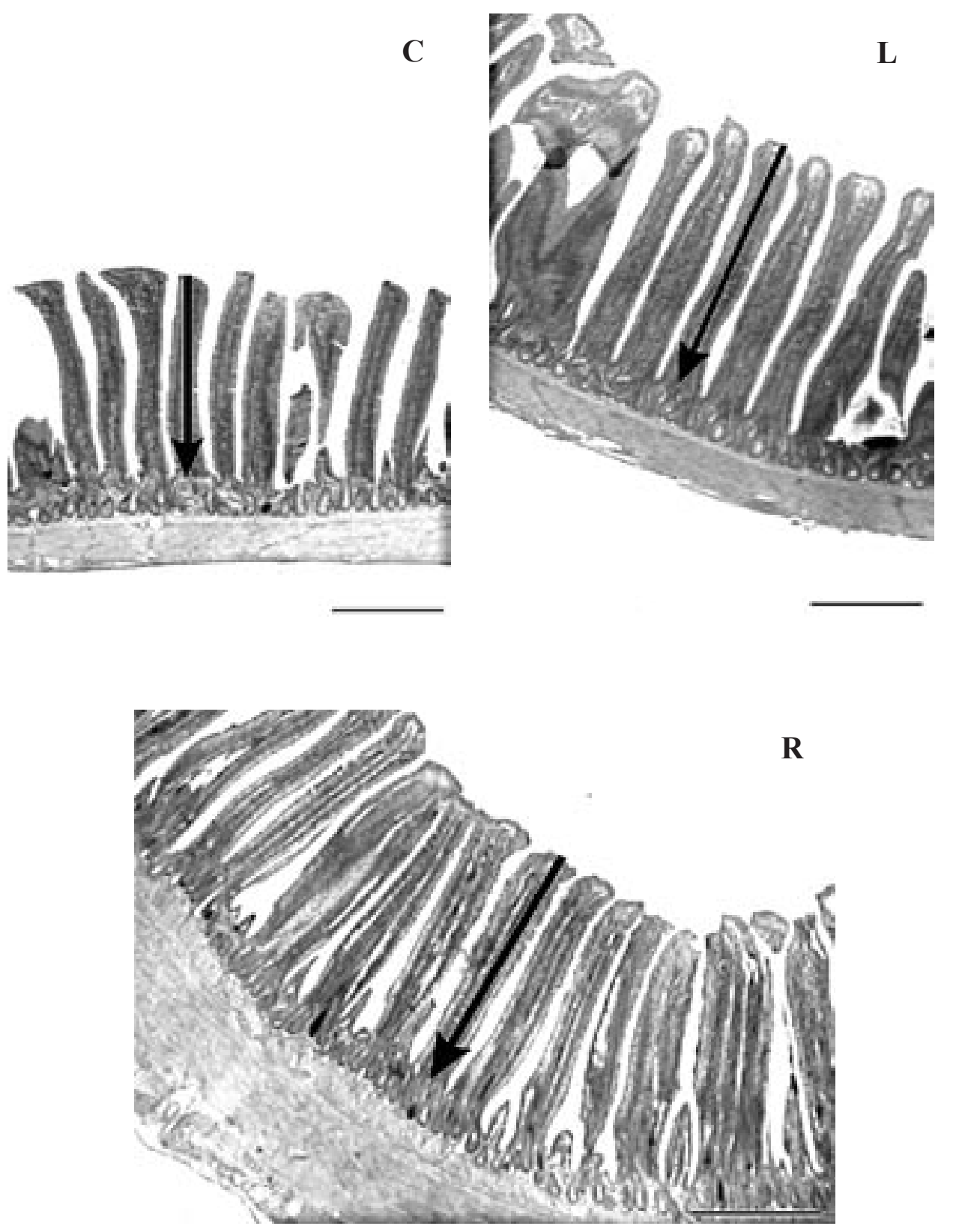

Figure 1. Microphotographs of the jejunum of 21 day-old chickens fed on diets: C - control, L - linseed, R - rapeseed. Arrow indicate height of villus. Scale bars $=500 \mu \mathrm{m}$. The higher villi were in jejunum of chickens fed with both experimental diets 

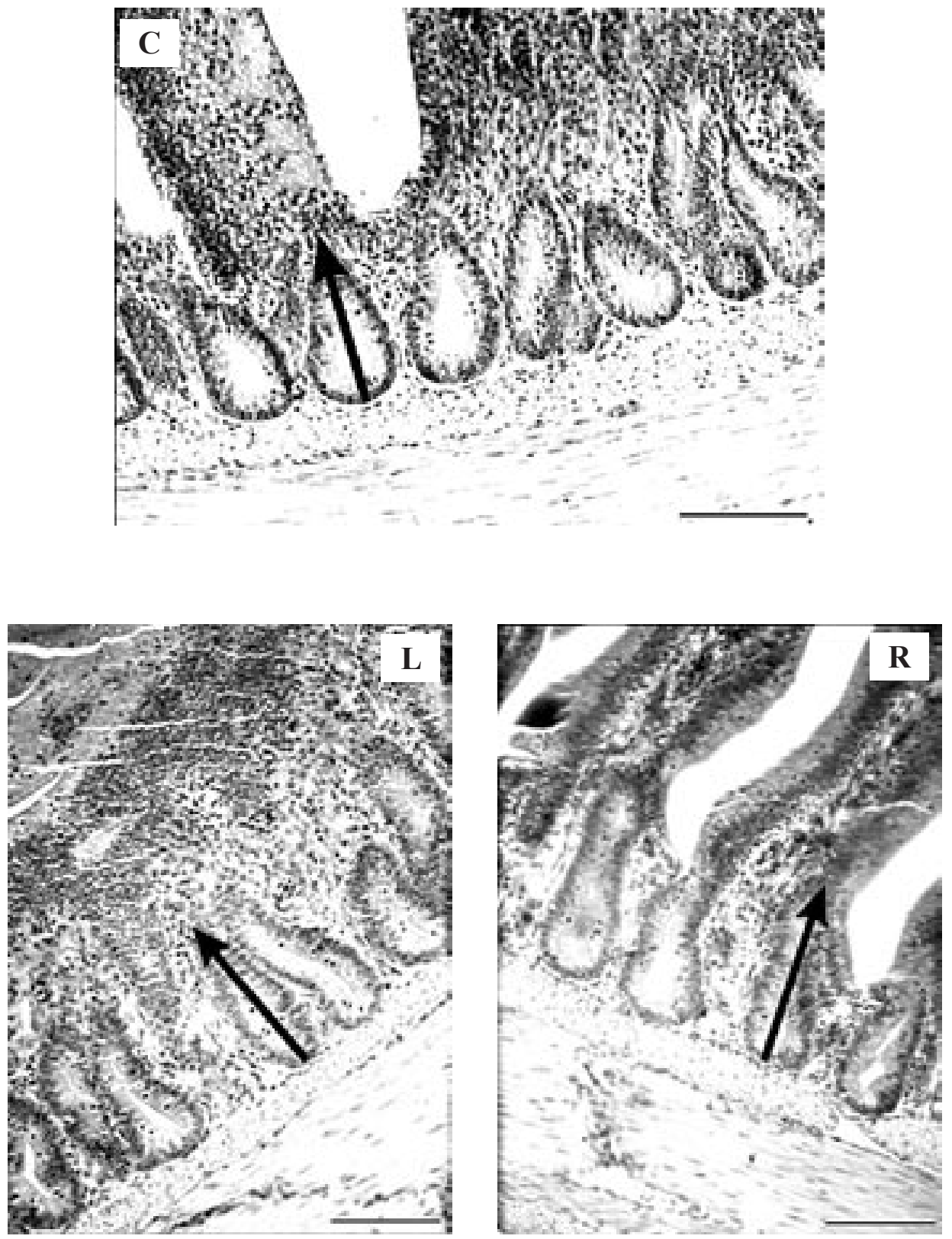

Figure 2. Microphotographs of the jejunum of 21 day-old chickens fed on diets: C - control, L - linseed, R - rapeseed. Arrows indicate depth of crypt. Scale bars $=100 \mu \mathrm{m}$. The deeper crypts were in jejunum of chickens fed with both experimental diets 


\section{DISCUSSION}

Linseed and rapeseed were the same, other dietary components, as well as composition of diets were similar as was described by Nguyen et al. (2003). In present study similarly as in work of Nguyen et al. (2003) the performance of chickens fed the diet with $100 \mathrm{~g} / \mathrm{kg}$ of rapeseed and $80 \mathrm{~g} / \mathrm{kg}$ linseed was not significantly different from control except that body weight gain in L group was higher than in $\mathrm{R}$ group due to higher feed intake. The little treatment effect on performance of broilers indicated, that antinutrients provided with both full-fat seeds at this dietary level had no harmful effect on birds. Similar results were reported by Lee et al. (1991) and Pietras et al. (2000). In all groups there was no evidence of any damage to the intestinal mucosa, it was composed of finger-like villi and simple tubular glands (crypts of Lieberkühn), which looked similarly as that presented by Humphrey and Turk (1974) and Turk (1982) in chickens fed standard diets. The descent of villi height and crypt depth from the duodenum to the ileum was consistent with that described in chickens by Turk (1982) and Iji et al. (2001a). The mucosal epithelium of small intestine is a complex tissue, constantly renewed by proliferation of stem cells in the crypts. Daughter cells from this area are pushed up along the side of villus, differentiate along the way, and upon reaching the apex of the villus are sloughed into the lumen of the intestine (Johnson, 1992). Most intestinal enzymes are secreted as inactive precursors at the crypt and acquire activity as enterocytes progress up the villus (Iji et al., 2001b). Pluske et al. (1996) showed, that in piglets an increase in crypt depth was compatible with an increase in crypt cell production rate and an overall stimulation of cell turnover in the small intestine was associated with a reduction in the digestive and absorptive capacity.

Chickens fed with linseed and rapeseed diets had higher villi and deeper crypts in jejunum and ileum than control chickens (Table 3). It may indicate for the shift in the digestion site of nutrients caused by both oilseeds, but mechanism of induction of hypertrophy of the villi may be slightly different. In the former study (Nguyen et al., 2003) linseed diet induced three times higher viscosity of jejunal digesta than control diet (4.5 vs $1.6 \mathrm{mPas} . \mathrm{s})$. Iji et al. (2001a) reported, that supplementation of broiler diet with highly-viscous NSPs caused an increase in villi height in jejunum and ileum. Intestinal enzyme activity was expressed over a larger proportion of the villus, enterocytes on longer villi continued to secrete enzymes for much longer than it was observed in the shorter villi. It has been demonstrated in rats that highly viscous fibres decrease accessibility of absorbable nutrients to the mucosal surface and hinder effective interaction of substrates and enzymes at the mucosal surface (Ikegami et al., 1990). The animal compensates for this inefficiency with an increased secretion of digestive juices.

Rapeseed diet in the former study (Nguyen et al., 2003) did not increased viscosity of small intestinal digesta in comparison with control group. However, 
about half of the total amount of fat in $\mathrm{R}$ diet was included in rapeseed. The liberation of fat from rapeseed, but also from linseed, even if both seeds were finely ground prior to inclusion into diet, had been slower than from control diet, and probably more fat reached more distal regions of the intestine. Johnson (1992) hypothesized, that delayed fat absorption in proximal intestine will be balanced by increased absorption at more distal sites. An increase in villus height in jejunum and ileum of chickens in $\mathrm{L}$ and $\mathrm{R}$ group indicated for adaptive response to exposition on greater supply of fat and other nutrients in digesta.

In the former study (Nguyen et al., 2003) the inclusion of both - lineseed and rapeseed into diet caused the decrease $\mathrm{pH}$ of ileal digesta in comparison with control group, what was indicative of proliferation of microflora in ileum. The chickens may adapt to it by increased thickness of intestinal wall, which is a physical and immunological barrier against harmful materials.

\section{CONCLUSION}

Diets containing moderate level of linseed or rapeseed alter morphology of mucosa mostly in distal parts of small intestine in broiler chickens, what indicates on a shift in a site of the absorption of nutrients within the digestive tract.

\section{REFERENCES}

Humphrey C.D., Turk D.E., 1974. The ultrastructure of normal chick intestinal epithelium. Poultry Sci. 53, 990-1000

Iji P.A., 1999. The impact of cereal non-starch polysaccharides on intestinal development and function in broiler chickens. World Poultry Sci. J. 55, 375-387

Iji P.A., Saki A., Tivey D.R., 2001a. Intestinal development and body growth of broiler chicks on diets supplemented with non-starch polysaccharides. Anim. Feed Sci. Tech. 89, 175-188

Iji P.A., Saki A., Tivey D.R., 2001b. Body and intestinal growth of broiler chicks on a commercial starter diet. 2. Development and characteristics of intestinal enzymes. Brit. Poultry Sci. 42, 514-522

Ikegami S., Tsuchihashi F., Harada H., Nishide E., Innami S., 1990. Effect of viscous indigestible polysaccharides on pancreatic-biliary secretion and digestive organs in rats. J. Nutr. 120, 353360

Jamroz D., Wiliczkiewicz A., Skorupińska J., 1992. The effects of feeds containing various levels of structural substances on morphological changes in intestinal walls and on the digestibility of the crude fibre fractions in geese (Part III). J. Anim. Feed Sci. 1, 37-50

Johnson I.T., 1992. The influence of dietary fibre on lipid digestion and absorption. In: T.F. Schweizer, C. Edwards (Editors). Dietary Fibre - A Component of Food-Nutritional Function in Health and Disease. Springer-Verlag, London: ILSI Europe, pp. 167-180 
Lee K.H., Olomu J.M., Sim J.S., 1991. Live performance, carcass yield, protein and energy retention of broiler chickens fed canola and flax full-fat seeds and the restored mixtures of meal and oil. Can. J. Anim. Sci. 71, 897-903

Nguyen C.V., Smulikowska S., Mieczkowska A., 2003. Effect of linseed and rapeseed on performance, slaughter yield and fatty acid composition in edible parts of carcass in broiler chickens. J. Anim. Feed Sci. 12, 271-288

Pietras M., Barowicz T., Gasior R., 2000. The effect of vegetable fat supplements on carcass quality and fatty acid profile of meat in broiler chickens. Ann. Anim. Sci. - Rocz. Nauk. Zoot. 27 (4), 209-219

Pluske J.R., Williams I.H., Aherne F.X., 1996. Maintenance of villous height and crypt depth in piglets by providing continuous nutrition after weaning. Anim. Sci. 62, 131-144

Rodriguez M.L., Alzueta C., Rebole A., Ortiz L.T., Centero C., Trevino J., 2001. Effect of inclusion level of linseed on the nutrient utilisation of diets for growing broiler chickens. Brit. Poultry Sci. 42, 368-375

Smulikowska S., 1998. Relationship between the stage of digestive tract development in chicks and the effect of viscosity enzymes on fat digestion. J. Anim. Feed Sci. 7, Suppl. 1, 125-134

Statgraphics ${ }^{\circledR}$ ver. 5.1. 1994-2001. Statistical Graphics System by Statistical Graphic Corporation, USA

Turk D.E., 1982. The anatomy of the avian digestive tract as related to feed utilization. Poultry Sci. $61,1225-1244$

Viveros A., Brenes A., Pizarro M., Castano M., 1994. Effect of enzyme supplementation of a diet based on barley, and autoclave treatment, on apparent digestibility, growth performance and gut morphology of broilers. Anim. Feed Sci. Tech. 48, 237-251

\section{STRESZCZENIE}

\section{Wpływ diet zawierających nasiona Inu lub rzepaku na morfologię śluzówki jelita cienkiego u kurcząt brojlerów}

Badano wpływ żywienia kurcząt brojlerów dietami zawierającymi nasiona lnu lub rzepaku na morfologię ściany jelita cienkiego. Trzy grupy po 12 kurcząt brojlerów żywiono od 8 do 21 dnia życia dietami pszenno-sojowymi, uzupełnionymi ksylanazą, i zawierającymi około $80 \mathrm{~g} / \mathrm{kg}$ tłuszczu surowego. Dietę kontrolną natłuszczano smalcem, dieta L zawierała $80 \mathrm{~g}$ nasion lnu, dieta R $100 \mathrm{~g}$ nasion rzepaku w $1 \mathrm{~kg}$. W trakcie doświadczenia mierzono przyrost masy ciała i wykorzystanie paszy, po czym po 17 godz. głodzenia ubito po 6 kurcząt z grupy i pobrano od każdego skrawki z 3 segmentów jelita cienkiego. Tkankę jelita utrwalono i zatopiono w paraplaście, po czym dokonano pomiarów histomorfometrycznych długości kosmków, głębokości krypt jelitowych i grubości warstwy mięśniówki i podśluzówki przy pomocy mikroskopu świetlnego.

Kurczęta z grupy L przyrastały nieco lepiej niż kurczęta z grupy $\mathrm{R}(\mathrm{P}<0.05)$ dzięki większemu spożyciu paszy, inne różnice we wskaźnikach wydajności były nieistotne statystycznie. Na podstawie obserwacji histologicznych śluzówki jelita cienkiego stwierdzono wydłużenie kosmków i pogłębienie krypt jelitowych oraz pogrubienie ściany jelita czczego i biodrowego u kurcząt $\mathrm{z}$ grup L i R w porównaniu z grupą kontrolną $(\mathrm{P}<0.05)$. Zmiany te mogą wskazywać na przesunięcie miejsca absorpcji składników odżywczych w obrębie przewodu pokarmowego kurcząt żywionych dietami z nasionami lnu i rzepaku. 